\title{
“Kibaki Tena?" The Challenges of a Campaign
}

\section{Anne Cussac}

\section{(2) OpenEdition}

\section{Journals}

Electronic version

URL: https://journals.openedition.org/eastafrica/679

DOI: 10.4000/eastafrica.679

ISSN: 2790-1076

\section{Publisher}

IFRA - Institut Français de Recherche en Afrique

\section{Printed version}

Date of publication: 1 April 2008

Number of pages: 35-55

ISSN: 2071-7245

\section{Electronic reference}

Anne Cussac, "Kibaki Tena?" The Challenges of a Campaign", Les Cahiers d'Afrique de l'Est / The East African Review [Online], 38 | 2008, Online since 19 July 2019, connection on 09 December 2021. URL: http://journals.openedition.org/eastafrica/679 ; DOI: https://doi.org/10.4000/eastafrica.679

This text was automatically generated on 9 December 2021.

Les Cahiers d'Afrique de l'Est / The East African Review 


\title{
"Kibaki Tena?" The Challenges of a Campaign
}

\author{
Anne Cussac
}

1 The 2007 electoral campaign, which took place in a confused partisan situation, was characterised by serious debate and true mobilisation which often took a violent turn. The campaign was very lively, pitting two men of diametrically opposed nature and vision against each other. At the same time, it raised a number of challenges that could have contributed to an exacerbation of violence after the announcement of the disputed presidential results.

2 At the end of the campaign, the voting process on 27 December 2007 was peaceful as compared to the post-election period. Before the elections, the competition was stiff between the two main political groupings-Mwai Kibaki's Party of National Unity (PNU) and Raila Odinga's Orange Democratic Movement (ODM). Additionally, the 2007 election was a test for Kibaki, who despite considerable socioeconomic successeconomic growth (6\% in 2006), and free primary education-found his position weakened by the haphazard management of his cabinet and his failure to keep several of his campaign promises. The numerous cabinet reshuffles and the entry of opposition members into government considerably stirred up controversy. ${ }^{1}$ Mainly, however, whereas Kibaki was elected on the grounds of his promise to fight corruption, several of his ministers were interrogated on these matters. ${ }^{2}$ Finally, although the promise of a new constitution was one of Kibaki's main campaign arguments, the government was further weakened by the rejection of its proposal during the referendum on 21 November 2005. ${ }^{3}$ Additionally, the voting process not only pitted two men against each other, but also two visions for the future of the country. M. Kibaki promised the continuation of his policies under the slogan Kibaki Tena ${ }^{4}$ while R. Odinga claimed that he would lead the country to a "third liberation," to heal it of corruption and tribalism. The context in which the campaign was held will be investigated in this paper in order to better understand why electoral fraud provoked such a violent reaction. 


\section{The complexity of political party stakes}

3 The three main groups in competition in 2007 emerged after the 2005 referendum, bearing witness to the rather opportunistic nature of partisan grouping. While these appeared as personal and ethno-regional enterprises, they coalesced in the search for access to national power and charged themselves not only ethnically but also politically according to the regions. In a parallel process, the only group with a national anchorage, Kenya African National Union (Kanu)-former single party-seemed weakened throughout the campaign period.

\section{Party confusion}

4 For the 2002 elections, Mwai Kibaki drew from an anti-Kanu front, the National Rainbow Coalition (NARC), which united the National Alliance of Kenya (NAK), which in itself was a coalition of 14 parties comprising the Democratic Party (DP), at that time headed by Mwai Kibaki, and Raila Odinga's Rainbow Alliance (then Liberal Democratic Party, LDP). Very soon after its victory in 2002, NARC split up. Frustrated by Kibaki's lack of respect for past agreements, ${ }^{5}$ the majority of LDP members of parliament close to Odinga joined Kanu, and became the main opposition party. This was the birth of the "Orange Movement," created to fight against the new constitution proposed by Kibaki. The rejection of the Constitution project by citizens during the November 2005 referendum eventually wrecked NARC with Kibaki having dismissed the ministers who called for a rejection of the document. The President no longer relied on a limited coalition and he lost a large part of his popular support. ${ }^{6}$ NARC was also affected by the departure of several of its MPs to other groups created much later, such as NARC-K and ODM. In total, about three-quarters out of 222 MPs in the Ninth Parliament changed their political party between 2002 and the end of 2006. ${ }^{7}$ Moreover, until Kibaki announced in October 2007 that he would be standing under the ticket of a new coalition, the Party of National Unity (PNU), three parties (DP, NARC, and a scission of NARC, NARC-Kenya) disagreed about him being their leader. Beyond these institutional aspects, ${ }^{8}$ this strong mobility led to a questioning of the significance and function of political formations in a country which, since independence, has lived under a de facto and de jure single party between 1982 and 1992.

5 African political parties have for a long time been a rather neglected object of study. The opening up to multipartyism in the 1990s, which gave rise to a multitude of fleeting groupings, barely improved the situation. ${ }^{9}$ Kenya was no exception and in November 2007, when the ECK made the final list of electoral candidates public, 134 political parties had been registered..$^{10}$ Nevertheless, just a few of them dominated the political scene and these changed names according to their whims for the elections but were nevertheless composed of the same members, who often had been engaged in politics for a long time. Added to this, the partisan formations did not translate to ideological differences and were mainly electoral machines of individuals who used them to their own interests. ${ }^{11}$

6 Moreover, because ethno-regional origins and patronage are central aspects in the political life of Kenyans, political parties are very often anchored in the region of their main leader and only rarely do they have a truly national nature apart from creating coalitions of politicians of different ethnicities, which probably explains their fragility. 
${ }^{12}$ For example, the Democratic Party (DP), created in December 1991 by M. Kibaki, dominates the Central Province, a Kikuyu-populated area. Ford-Kenya is associated with Western Kenya and Musikari Kombo. In the same vein, the Orange Democratic Movement-Kenya (ODM-K), of the presidential candidate Kalonzo Musyoka who belongs to the Kamba ethnic group, enjoyed an audience limited to Ukambani.

7 Taking into account the large ethnic dispersion in the country, ${ }^{13}$ in order to endear themselves to the electorate, politicians have no choice but to mobilise voters outside of their ethnic block. Presidential aspirants were therefore heavily involved in mobilising their allies across the country quite early on, in an attempt to play the multi-ethnic card. For example, M. Kibaki relied on Daniel Moi and Kipruto Kirwa (both Kalenjin) in the Rift Valley, on Chirau Ali Makwere (Mijikenda) in the Coast, on Musikari Kombo (Luhya) in the West, and on Simeon Nyachae (Gusii) in the Kisii region. R. Odinga, on his part, benefited from Musalia Mudavadi's (Luhya) popularity in the West, from Najib Balala (Arab) at the Coast, from Joseph Nyaga (Mbeere) in central Eastern, and from Fred Gumo (Luhya) and Reuben Ndolo (Luo) in Nairobi.

Despite all this, the institutional weakness of the political parties manifested itself during the primaries for the designation of candidates to parliamentary and local seats. ${ }^{14}$ These nominations unfolded in a chaotic and often violent manner, and several candidates who lost in the large parties kept their candidacy by joining less well-known political parties. ${ }^{15}$

\section{Kanu's unlikely recovery}

9 Kanu, the oldest party in the country, dictatorial under Kenyatta and Moi, never emerged from its 2002 retreat. ${ }^{16}$ Officially having been at the head of the opposition, the political party saw about half of its leadership rally behind ODM, with the exception of Uhuru, the son of Jomo Kenyatta. In 2007, its weakened state was confirmed as, for the first time in its history, the party had no candidate in the presidential elections and was represented in a few constituencies for parliamentary elections. ${ }^{17}$ Kanu's fragility was distinct in the parliamentary elections of 1997 , where it won only four seats..$^{18}$ In the run-up to the 2002 polls, while Moi unilaterally chose Uhuru Kenyatta as his successor, he encountered criticisms and defections. The prevailing difficulties in Kanu certainly owed much to Kenyatta, an inexperienced and highly criticised politician within the party. In January 2005, after his elevation to party chairman, Nicholas Biwott, a historic figure in Kanu, created a dissident group for some time before returning to the main party.

10 And so it was that Uhuru Kenyatta found himself at the head of a divided Kanu, deserted by several of his former members. A faction coalesced around Njenga Karume and thus identified with the Kibaki government, with other MPs from Kiambu. On the other hand, the majority of Kanu MPs from the Rift Valley associated themselves with ODM at the end of 2005 , and were led by W. Ruto. The latter wanted to enter into a coalition in 2007 while Moi believed that Kanu could manage on their own in the parliamentary elections. The battle between the two men was not only about the leadership of the formation but also about the leadership of the Rift Valley Kalenjin community. Rift Valley is the region with the highest number of voters, amounting to about 3.5 million. Throughout his presidency, Moi largely controlled the Kalenjin vote, and in 2007 , he attempted to win over his voters to support Kibaki. ${ }^{19}$ In 2002, many 
Kalenjin followed him by voting for Kenyatta, then in 2005, against the constitutional reforms project. However, Moi's popularity crumbled and is today limited to the political and economic elite from the Rift Valley, as well as those of his Tugen community. For his part, Ruto had the support of the youth and the poor, as well as the Kipsigis and Nandi sub-groups. On the other hand, Kibaki had very little popularity among the Kalenjin who had not forgiven him for sacking many of their community members from the positions of authority that they had acquired under Moi's rule. The alliance between Moi and Kibaki in 2007 was ultimately ambiguous, as Kenyatta, Kibaki's adversary in 2002, campaigned for him in 2007!

\section{Pre-electoral violence changes}

11 Pre-electoral violence, a recurring occurrence after the beginning of multipartyism, became a tool used by the government to stamp its dominance in the Kenyan society. ${ }^{20}$ Termed ethnic confrontations, land battles, livestock theft, border clashes or banditry, these acts, occurring in a local framework of deep conflict, also had a hidden agenda of terrorising the populations suspected of supporting the opposition, in order to prevent them from voting. Despite this, the 2002 elections demonstrated the failure of the State-sponsored violence, ${ }^{21}$ as it could not prevent NARC's victory over Kanu. Several people who had been responsible for the violence in 1992 and 1997 had since joined the opposition, thus weakening Kanu's capacity to mobilise militia. ${ }^{22}$ Additionally, in 2002 the two main candidates were Kikuyu. Choosing on ethnic grounds was therefore impossible both for the Kikuyu as for the other Kenyans. ${ }^{23}$

In 2007 , the situation was quite different as the most serious presidential candidates were from different ethnic communities, considered as politically antagonistic. There were therefore fears that the identity themes would be manipulated for political ends. Nevertheless, it is difficult to affirm that the pre-electoral violence was a preview of the events after the announcement of the results, even if the reaction of the losers could have been worrying, due to the stiffness of the competition. In reality, the pre-electoral confrontations resulted in a resurfacing of previous problems. This paper will discuss the cases of Molo, a rural area, and of the Mungiki movement in the urban settings.

13 Molo district was the epicentre of violence in 1992. During the 2007 campaigns, the violence mainly affected Kuresoi district, where hundreds of houses were burnt down and several dozens of people killed between October and December. ${ }^{24}$ The region had experienced an old land problem, linked to the establishment of "squatters" from the Central province, in the colonial era. ${ }^{25}$ In a situation where thousands of Kalenjin were chased away from Mau Forest in Molo District by the Kibaki government where they had illegally settled, the Kalenjin believed that the land in the area was theirs by right. Kenya is an agrarian society where access to land is a fundamental issue. It is used by some members of the elite for political ends, by resorting to fear tactics. For example, among the Kikuyu, fear rested on the idea that if they lost the presidency, they would also lose their land. In Molo, the Kikuyu are considered by the Kalenjin as illegitimate holders of the land and in this context, the land battle easily transformed into a macropolitical conflict. Kalenjin leaders also played on this resentment inciting the rural poor within their community to expel their Kikuyu neighbours, promising to give them the abandoned lands. Described as a response to livestock theft, the violence in fact aimed at removing not only the Kikuyu but also the Kisii, considered as favouring 
President Kibaki-a Kikuyu-and PNU, to prevent them from taking part in the election. The authorities were then blamed for their passivity in view of the serious problems experienced in both Molo and Mount Elgon, whereas they concentrated on the fight against Mungiki in the capital city. In these regions, far-flung from the main centres of power, the violence mainly concerned local actors and did not threaten the government organs, as opposed to the troubles that affected the capital and which were violently repressed.

In March 2002, after the confrontations that opposed two militia groups (the Kikuyu Mungiki movement and the Luo Taliban) in Nairobi, all vigilant groups were banned by the Kibaki administration. ${ }^{26}$ Despite this ban, Mungiki members supported Uhuru Kenyatta's candidacy in December 2002. After his failure, the sect members-mainly comprising unemployed youth-felt abandoned by the Kikuyu elite. Reconverted into a militia controlling residential areas that had been neglected by the government, the sect specialised in clandestine economic activities and settling of scores, ${ }^{27}$ progressively evading control by politicians. As the group was well established in Nairobi and it had spread into the society and the State, Mungiki was a challenge for the authorities. Therefore, from June 2006, the Kibaki regime launched an attack against the sect, resulting in confrontations between the Mungiki members and the police in the Mathare slums and in some rural areas of Central Province. Additionally, after the arrest of its former leader, Maina Njenga, in February 2007, followed by his five-year jail term in May, the group increased its extremely violent activities, which the police responded to brutally. ${ }^{28}$ However in 2005, Maina Njenga had supported M. Kibaki in calling for a "Yes" vote in the constitutional referendum and in 2007, Mungiki had again mobilised in support of Kibaki under the umbrella of the Kenya Youth Alliance. Nevertheless, because of its increasingly violent acts, Mungiki became unpopular among the Kikuyu middle class and divides the politicians of this community. The group is still said to have the support of influential politicians and some Kikuyu Ministers such as John Michuki (Internal Security), Maina Kamanda (Sports) and Njenga Karume (Defense) are suspected to have links with the sect. But for the Kikuyu elite, which needed to control its bases, it was also a matter of maintaining their control on the sect, even if it implied a "sacrifice" of some of its members. In this battle, largely illegally carried out, hundreds of supposed Mungiki adherents were killed mercilessly.

According to the Kenya National Commission of Human Rights (KNCHR), more than 500 young men, mainly Kikuyu, were killed by the police between June and October 2007. Their bodies were placed in several mortuaries across the country or abandoned in the fields. ${ }^{29}$ The repression against the sect was on the headlines throughout this period even if, apart from these violent acts, real debates also marked the campaign.

\section{A campaign of explosive debate}

The campaign was structured by several highly sensitive themes and the promises made elicited huge expectations, particularly among the underprivileged groups in the country, the poor and the youth. While the majimbo ${ }^{30}$ issue solidified the competition between the two main parties, it also pit two men, of opposing views and personalities, against each other. 


\section{Revisiting the majimbo controversy}

17 Promising "growth and poverty reduction," the presidential candidates disagreed on the issue of regionalism, better known as majimbo. This issue was at the core of the constitutional debate in the 1960s and at independence, Kenya adopted a federal system whereby each province had its own government. This experiment failed due to the incapability of some regions to govern themselves and the fierce opposition by Jomo Kenyatta, who became the Prime Minister in $1963 .{ }^{31}$ Thus, under the Kanu government, regionalism was abandoned for centralisation. In the 1990s, the term reemerged with one specific meaning, linked with ethnic violence in the Rift Valley, Nyanza, and the Coastal region. As the Kenyatta regime favoured the Kikuyu and associated groups-Embu and Meru-a large proportion of the country's wealth belonged to this new elite, grouped within the Gikuyu Embu Meru Association (Gema). Hence, under Moi's rule and "to protect the integrity of the small tribes that were at the risk of being choked by the larger ones, such as the Kikuyu"32 some Kanu strong men, for example N. Biwott, William ole Ntimama, and Kipkalya Kones referred to majimbo and formed a coalition named Kamatusa (KAlenjin, MAasai, TUrkana, SAmburu) aimed at uniting these different communities. In an attempt to strengthen their power in a situation of growing demand for multipartyism, they defended the concept to promote a federal system based on ethnicity, involving the expulsion of "non-indigenous" groups, particularly the Kikuyu, but also the Luo and Luhya, to their land of origin. ${ }^{33}$

While the idea of majimbo was called upon by ODM during the campaign as a form of regionalised government that would benefit the poorest provinces, its reactivation was not without danger due to the multi-faceted meanings of the word, which also had negative connotations. Thus, even if they denied it, some in the ODM shared the ethnic vision of majimbo. Among them was William Ole Ntimama who, during the 1997 polls, presented himself as the strongest defendant of the rights of the Maasaï community against the Kikuyu in his Narok district. On the PNU side, it is due to its (majimbo) potential for conflict that the party opposed the idea, but also because the Kikuyu community was the first victim of its ethnic use. Regionalism as a concept reappeared during the constitutional discussions from the end of the 1990s, as a response to the centralised government model. The idea of "devolution" thus became one of the most discussed themes, with the feeling that it allowed the promotion of minority interests and marginalised groups, and a more equitable sharing of resources in a society rife with inequalities. After the failure of the constitutional reform, some candidates, starting with Raila Odinga, once more took up the idea of decentralisation and suggested the introduction of majimbo to guarantee a more equal sharing of power between the centre and the periphery, and a better distribution of resources. From a political point of view, the idea was good as the theme and its ethnic undertones were very popular in some areas, such as the Coast, which had a substantial voter base of about 1.1 million. In the Central Province, with a majority Kikuyu population and already in the bag for Kibaki, the idea was unpopular, as it was a reminder of the violent acts aimed at the Kikuyu in 1992 and 1997. Odinga therefore had to unite all regions of the country, in his favour, against the Kikuyu. ${ }^{34}$

19 This resurgence of the issue revealed a deep tension between the region and the nation and brought to light greater challenges, reflecting the limits of the government model that Kenya had maintained since independence. This was characterised by an all- 
powerful presidency and the absence of real power-sharing in a context where an exclusive ethno-regional conception of power leads many "wananchi" to think that it is only the ethnic group of the President that benefits from the fruits of power. The majimbo idea was a reminder of the problems of unequal allocation of resources between the various regions, efficiency, political transparency in development as well as citizen participation. The promotion of the principle by Odinga was also part of his speeches on the need for change, in opposition to the continuity promised by Kibaki.

\section{Two men, two images} political battle between the Luo and Kikuyu, which has fired up political imagination in Kenya since independence. The potential victory of Raila Odinga would have been a return to history, ${ }^{35}$ and his accession to the presidency would have represented a victory against the Kikuyu, accused of having hoarded power. ${ }^{36}$ Besides, having renounced his candidature to support M. Kibaki in 2002, the Luo leader held onto 2007 as his best chance of accessing the presidency. He sought to give himself a national image, describing himself as "The People's Candidate" against the Kenyatta and Moi ${ }^{37}$ dynasties. He promised a "third liberation" after independence and the 2002 political transition, to cure the country of corruption and tribalism. Thanks to his campaign themes, R. Odinga was very popular among the youth of all ethnic groups, who were strongly affected by unemployment in a system tainted by inequalities. In comparison, Kibaki appeared as the candidate for the business class, ${ }^{38}$ basing on his economic record to promise that "the work would continue." 39

21 More than the ethnic factor, the opposition between the two forms of power that structured the campaign explains why the failure of "The People's Candidate" resulted in such an outpouring of violence in poor areas of the towns, where the youth and the poor, having barely benefited from economic growth and the effects of government policies, had placed high hopes on the possibility of a change in power.

Despite disequilibrium in the candidates' resources (for example in access to public media and in the use of State machinery), throughout his campaign, Odinga demonstrated his skill in using images and shock tactics, also confirming his capacity to mobilise crowds and sustain popular enthusiasm. He had proved this particular skill in 2002 during the NARC campaign and contributed to Kibaki's victory. Faced with an apparatchik like Kibaki, Odinga played on his past as a prisoner and opponent of the Moi regime. He appeared as a master propagandist, playing the conspiracy card and posing as a victim. During the campaign, for example, he affirmed that the difficulties surrounding the registration of ODM were part of the Executive's strategy to weaken the opposition or that the failure to renew the mandate of the Vice-President of the Electoral Commission was intended to rig the elections. Besides, the composition of this Commission raised controversy throughout the campaign, as all members of this body that had controlled the 2007 elections had been appointed or had had contracts renewed by Mwai Kibaki. ${ }^{40}$ Nevertheless, the latter tried more than to show that he had the strength for a second term ${ }^{41}$ to prove the independence of the Commission. On the opposite, his two main challengers, R. Odinga and K. Musyoka had the advantage to been seen as "young" and dynamic, K. Musyoka, the outsider, capitalised on his "Mr. Clean" image by making his personal wealth public, as a sign of his dedication to

Les Cahiers d'Afrique de l'Est / The East African Review, 38 | 2008 
financial transparency and the battle against corruption. ${ }^{42}$ Basing on the strong religious nature of the Kenyan society, he also used his reputation for piety and of being a born-again Christian, using terms such as "miracle" and "prophecy" during the launching of his campaign at Uhuru Park in October 2007. He believed that he would surprise everyone by snatching the presidency from the two favourites..$^{43}$ The politicians thus played off on values (faith, health, honesty) and not only on political networks or on ethnicity.

Religion was actually a recurrent theme throughout the electoral campaign, especially after the rendering public of the agreement between R. Odinga and a group of Muslim leaders, in which he committed to regularly respond to the critiques of the group, ${ }^{44}$ in exchange for the support of the religious leaders. Despite having to endure the criticism of some Christian leaders, this agreement allowed Odinga to ally himself with the influential Muslim minority, towards whom Kibaki also increased efforts. ${ }^{45}$ It is nevertheless quite surprising that the Muslim representatives took up as much media space as they eventually did. This is because Christian churches have always appeared as the most influential religious structure in the public arena, playing a fundamental role in the political debate in both 1992 and $1997 .{ }^{46}$ During the campaign in 2007, just as in 2002, most Christian leaders took a neutral stance, simply reminding citizens of the importance of voting and of holding free, fair and peaceful elections.

Whereas the outburst of violence that affected Kenya after the announcement of the controversial results of the presidential elections may have surprised most observers, it is nevertheless irrefutable that all through the campaign period, there was evident tension, given the stakes and the explosive nature of some topics such as majimbo or the unequal access to resources. By promising a sharing of power and national wealth and by posturing as the candidate for the underprivileged masses, Raila Odinga created huge hopes among the youth and the poorest of society. The violence that broke out from 27 December 2007 were mostly an expression of the disappointments of those who had voted for change in 2002 and had not experienced any improvement in their situation. Having expressed their desire for "a better life" 47 through voting, after the failure of their candidate, a section of the population resorted to violence not only to express their anger but also to appropriate the wealth that they had hoped to have access to. ${ }^{48}$

\section{BIBLIOGRAPHY}

ANDERSON, D.M. (2005). 'Yours in the struggle for Majimbo.' Nationalism and the party politics of decolonization in Kenya, 1995-1964.' Journal of Contemporary History 40 (3): 547-564.

ANDERSON, D.M. (2003). 'Le déclin et la chute de la Kanu. La recomposition des partis politiques dans la succession de Moi (Kenya).' Politique Africaine 90: 37-55.

ANDERSON, D.M. (2002). 'Vigilants, violence and the politics of public order in Kenya.' African Affairs 101 (405): 531-555. 
ASINGO, P.O. (2003). 'The political economy of transition in Kenya' in W.O. OYUGI, P. WANYANDE, C.O. MBAI (eds.), The Politics of Transition in Kenya. From Kanu to Narc. Nairobi: Heinrich Boll Foundation.

BASEDAU, M., ERDMANN G., MEHLER, A. eds. (2007) Votes, Money and Violence. Political parties and elections in sub-Saharan Africa. Uppsala, Nordiska Afrika Institutet, Scottsville: KwaZulu-Natal Press.

BROWN, S. (2004). 'Theorising Kenya's protracted transition to democracy.' Journal of Contemporary African Studies 22 (3): 332-333.

CHARTON, H., MEDARD, C. eds (2007). Annuaire de l'Afrique orientale 2005. Paris: L'Harmattan.

ERDMANN, G. (2004). 'Party research: Western European bias and the "African labyrinth"', Democratization 11 (3): 63-87.

ERDMANN G., BASEDAU M. (2007). Problems of categorizing and explaining party systems in Africa, Giga Working Papers, no. 40.

GAZIBO, M. (2006). 'Pour une réhabilitation de l'analyse des partis en Afrique.' Politique Africaine 104: 8.

KAGWANJA P. (2003). 'Facing Mount Kenya or facing Mecca? The Mungiki, ethnic violence and the politics of the Moi succession in Kenya, 1987-2002.' African Affairs 102 (406): 25-49.

KANYINGA, K. (2003). 'Limitations of political liberalisation: parties and electoral politics in Kenya, 1992-2002.' In W.O. OYUGI, P. WANYANDE, C.O. MBAI (eds.), The Politics of Transition in Kenya. From Kanu to Narc. Nairobi: Heinrich Boll Foundation (pp. 96-127).

KAGWANJA, M. (1998). Killing the Vote. State-sponsored Violence and Flawed Elections in Kenya. Nairobi: Kenya Human Rights Commission.

KLOPP, J.M. (2002). 'Can moral ethnicity trump political tribalism? The struggle for land and nation in Kenya.' African Studies 61 (2): 269-294.

MAUPEU, H. (2005). 'Religion and the elections.' In H. MAUPEU, M. KATUMANGA, W. MITULLAH (eds.). The Moi Succession. Elections 2002. Nairobi: Transafrica Press.

MAUPEU, H. (2002). 'Mungiki et les élections. Les mutations politiques d'un prophétisme kikuyu (Kenya).' Politique Africaine 87: 117-137.

MAUPEU, H. (2001). 'The churches and the polls.' In M. RUTTEN, MAZRUI, F. GRIGNON (eds.). Out of the Count: the 1997 General Elections and Prospects of Democracy in Kenya. Kampala: Fountain Publishers (pp. 50-71).

MÉDARD, C. (1998). 'Dispositifs électoraux et violence ethniques: réflexions sur quelques stratégies territoriales du régime kényan.’ Politique Africaine 70: 32-39.

MORTON, A. (1998). Moi: The making of an African Statesman. London: Michael O’Mara Books.

MUTAHI, P. (2005). 'Political violence in the elections.' In H. MAUPEU, M. KATUMANGA, W. MITULLAH (eds.). The Moi Succession. Elections 2002. Nairobi: Transafrica Press (pp. 69-95).

MUTUNGA, W. (1999). Constitution-Making from the Middle. Civil Society and Transition Politics in Kenya, 1992-1997. Sareat.

ODHIAMBO, E.S.A (2004). 'Hegemonic enterprises and instrumentalities of survival: ethnicity and democracy in Kenya.' In BERMAN, D. EYOH, W. KYMLICKA (eds.). Ethnicity and Democracy in Africa. Oxford: James Currey (pp. 167-182). 
OLOO, A. (2005). 'The Raila factor in Luoland' in H. MAUPEU, M. KATUMANGA, W. MITULLAH (eds.), The Moi Succession. Elections 2002. Nairobi: Transafrica Press.

WANYANDE, P. (2003). 'The politics of alliance building in Kenya: the search for opposition unity.' In W.O. OYUGI, P. WANYANDE, O. MBAI (eds.), The Politics of Transition in Kenya. From Kanu to Narc. Nairobi: Heinrich Boll Foundation.

\section{NOTES}

1. Both in 2004 and 2005, members of Ford-People and Kanu joined the government, despite being in the Opposition.

2. David Mwiraria, Kiraitu Murungi and Chris Murungari, as well as Kibaki's personal assistant Alfred Getonga and the vice-president Moody Awori were cited in the AngloLeasing financial scandal. George Saitoti, the architect of free primary education was interrogated in the Goldenberg affair.

3. The document was rejected by $57 \%$ votes. For more on its origins and and the revision process, see W. Mutunga, Constitution-Making from the Middle. Civil Society and Transition Politics in Kenya, 1992-1997, Sareat, 1999; the chapter in H. Charton and C. Medard (dir.), Annuaire de l'Afrique orientale 2005, Paris, L'Harmattan, 2007, p. 59-128.

4. Kibaki Tena, meaning "Kibaki once more," was the campaign slogan of the incumbent president.

5. Contrary to what was expected, the positions were unequally distributed; the first government appointed by M. Kibaki had 17 NAK ministers and only 8 from LDP.

6. L. Maina, F. Waswa and S. Waiyego, 'Pitfalls in constituion-making in Kenya: experiences from Bomas and the 2005 national referendum.' In H. Charton and C. Médard (dir.), Annuaire de l'Afrique orientale 2005, op. cit., p. 123.

7. 'New bull to tame political parties.' Sunday Nation, 3 December 2006, p. 7. Odinga had changed his political affiliation seven times, while Kibaki had done so five times. See 'Masters of defection: Raila and Kibaki lead.' The Standard, 13 September 2006, p. 1-2.

8. There is no specific law on the formation, management and funding of political parties. The proposed law on this issue in 2007 was not signed by Kibaki before the dissolution of Parliament.

9. Political parties in Africa today seem to attract more interest. See G. Erdmann, 'Party research: Western European bias and the "African labyrinth." Democratization, vol. 11, no 3, 2004, p. 63-87; M. Gazibo, 'Pour une réhabilitation de l'analyse des partis en Afrique.' Politique Africaine, no 104, December 2006, p. 8; G. Erdmann and M. Basedau, Problems of categorizing and explaining party systems in Africa, Giga Working Papers, no 40, 2007; M. Basedau, G. Erdmann and A. Mehler, Votes, Money and Violence. Political parties and elections in sub-Saharan Africa, Uppsala, Nordiska Afrika Institutet, Scottsville, KwaZulu-Natal Press.

10. www.eck.or.ke/downloads/politicalparties.pdf [not available. Last archive]. More than 300 political formations were recognised by the Attorney General, but only half of them were registered with the ECK.

11. P. Wanyande, 'The politics of alliance building in Kenya: the search for opposition unity.' In W.O. Oyugi, P. Wanyande and C.O. Mbai (eds.), The Politics of Transition in Kenya. 
From Kanu to Narc, Nairobi, Heinrich Boll Foundation, 2003, p. 148. The Kenya Democratic Alliance (Kenda) is significant in this case. This grouping, created by Kamlesh Pattni, a businessman implicated in the Goldenburg scandal, allowed him to change his image.

12. However, Kanu was an exception and enjoyed a national reach.

13. Kenya has 42 ethnic groups which are basically concentrated in certain regions: Kikuyu in Central Province, Luo in Nyanza Province and Luhya in Western Province.

14. PNU, ODM and ODM-K had chosen to hold the primaries for the choice of their candidates in the local and parliamentary elections. These unfolded in a rather disorganised manner because in theory, only party members were eligible to vote, it turned out that an identity card and voter's card were sufficient for one to participate. This resulted in a situation where, for example, a PNU member could take part in ODM primaries and vice versa.

15. Kenda is also of interest in this instance, because as it did not have presidential candidates, it registered a considerable number of parliamentary aspirants, having benefited from an increase of several hopefuls left out during the primaries of the main political parties.

16. D. Anderson, 'Le declin et la chute de la Kanu. La recomposition des partis politiques dans la succession de Moi (Kenya).' Politique Africaine, $\mathrm{n}^{\circ}$ 90, June 2003, p. 3755.

17. Kanu rallied around PNU to support Kibaki's candidacy to the presidency, but kept its own candidates for the local and parliamentary elections.

18. K. Kanyinga, 'Limitations of political liberalisation: parties and electoral politics in Kenya, 1992-2002.' In W.O. Oyugi, P. Wanyande, C.O. Mbai (eds.), The Politics of Transition... op. cit., p. 96-127.

19. Moi supported Kibaki as Kanu did not have a presidential candidate. But he intended his party to present its own candidates in the parliamentaries and not under the banner of PNU.

20. M. Kagwanja, Killing the Vote. State-sponsored Violence and Flawed Elections in Kenya, Nairobi, Kenya Human Rights Commission, 1998.

21. P. Mutahi, 'Political violence in the elections.' In H. Maupeu, M. Katumanga, W. Mitullah (eds.), The Moi Succession. Elections 2002, Nairobi, Transafrica Press, 2005, p. 6995.

22. S. Brown, 'Theorising Kenya's protracted transition to democracy.' Journal of Contemporary African Studies, vol. 22, n 3, 2004, p. 332-3.

23. P. O. Asingo, 'The political economy of transition in Kenya.' In W.O. Oyugi, P. Wanyande, C.O. Mbai (eds.), The Politics of Transition..., op. cit., p. 39.

24. 'Why decades-old conflict is unlikely to end soon.' Daily Nation, 5 December 2007, p. 32 .

25. Under colonisation, the Kikuyu, chased away from the Central Province by the British colonialists, settled in the Rift Valley and at independence, taking advantage of their political and economic dominance, settled in large numbers in the region.

26. Several private militia were created in the 1990s in order to provide security in certain areas where the government had absconded its role. These gangs made the slum-dwellers pay for their security, for water and electricity. Mungiki stands out in 
this matter. Created as a socio-religious group to revive Kikuyu traditions, the movement progressively transformed into a violent militia. Mungiki is concentrated in several slums of Nairobi and in some parts of the Central and Rift Valley provinces. It controls the matatu industry in areas of low populations. See D. Anderson, 'Vigilants, violence and the politics of public order in Kenya.' African Affairs, vol. 101, $\mathrm{n}^{\circ} 405,2002$, p. 531-555; H. Maupeu, 'Mungiki et les élections. Les mutations politiques d'un prophétisme kikuyu (Kenya).' Politique Africaine, n 87, October 2002, p. 117-137 ; P. Kagwanja, 'Facing Mount Kenya or facing Mecca ? The Mungiki, ethnic violence and the politics of the Moi succession in Kenya, 1987-2002.' African Affairs, vol. 102, $\mathrm{n}^{\circ} 406,2003$, p. 25-49.

27. Mungiki is a sect that follows several codes and rituals. After having taken the oath, if a member of the group leaves, he is considered as a traitor. Several members of the sect who tried to leave it were assasinated.

28. Maina Njenga had intended to present Mungiki candidates in the elections. This was a threat to M. Kibaki who needed to control his Kikuyu base.

29. See www.knchr.org/dmdocuments/Execution_Disappearance.pdf [not available. See archive].

30. Jimbo (majimbo pl.) is a Kiswahili word meaning region.

31. In 1964, Kenyatta amended the Constitution to set up a highly cenytralised republic, of which he becane president. See D.M. Anderson, 'Yours in the struggle for Majimbo.' Nationalism and the party politics of decolonization in Kenya, 1995-1964.' Journal of Contemporary History, vol. 40, $\mathrm{n}^{\circ}$ 3, 2005, p. 547-564.

32. A. Morton, Moi: The making of an African Statesman. London, M. O'Mara Books, 1998, p. 108.

33. Asserting that the Rift Valley was Maasai and Kalenjin territory, they encouraged their supporters to expel members of other ethnic groups, suspected of voting for the opposition. The violence cost 1500 people their lives and displaced at least 300,000 others. See C. Medard, 'Dispositifs électoraux et violence ethniques: réflexions sur quelques stratégies territoriales du régime kényan.' Politique Africaine, $\mathrm{n}^{\circ} 70$, September 1998, p. 32-39 ; J.M. Klopp, 'Can moral ethnicity trump political tribalism ? The struggle for land and nation in Kenya.' African Studies, vol. 61, n 2, 2002, p. 269-294.

34. Daily Nation, 30 October 2007.

35. Having refused the offer from the British to lead Kenya while Jomo Kenyatta was not free, Oginga Odinga let him take over the leadership of the country.

36. E.S.A. Odhiambo, 'Hegemonic enterprises and instrumentalities of survival: ethnicity and democracy in Kenya.' In B. Berman, D. Eyoh, W. Kymlicka (eds.), Ethnicity and Democracy in Africa, Oxford, James Currey, 2004, p. 167-182; A. Oloo, 'The Raila factor in Luoland.' In H. Maupeu, M. Katumanga, W. Mitullah (eds.), The Moi Succession. op. cit., p. 159-196. The Luo were believed to have been margianlised under Kenyatta and Moi and the proof is in the marginalisation or assassination of principal Luo political figures such as Oginga Odinga, Tom Mboya and Roibert Ouko.

37. For Odinga, the Kibaki-Moi-Kenyatta alliance aimed to guarantee this supremacy and Kenyatta agreed to support Kibaki in 2007 in exchange for his support in the 2012 elections.

38. An economist trained at Makerere University, then at London School of Economics, Kibaki is a political veteran--elected since 1963, he was Vice-President in the Moi 
regime, after which he became an opposition figure in the 1990s and founded the Democratic Party.

39. Kazi iendelee-may the work continue-was a PNU slogan.

40. According to an agreement completed in 1997, the opposition should have proposed names for half the members of the commission. However, this agreement was never subjected to law and therefore, the President had no obligation to honour it.

41. On a visit in Mombasa, Kibaki walked the streets to prove that he had the energy and vitality to take on second term. Sunday Nation, 14 October 2007.

42. Daily Nation, 13 December 2007.

43. 'ODM-K launches campaign.' Daily Nation, 15 October 2007.

44. These demands were mainly on the delay in the obtaining identification papers, harassment of some Muslims who they claimed were victimised by the authorities within the framework of the fight against terrorism or their marginalisation in terms of education and employment.

45. In October, Kibaki formed a team to consider the issues raised by the Muslims (discrimination, harrassment) and he also announced the setting up of of an office for issuing of passports to Muslims, in order to facilitate their pilgrimages to Mecca.

46. For more on the relationships between the Churches and politics, refer to $\mathrm{H}$. Maupeu, 'The churches and the polls.' In M. Rutten, A. Mazrui and F. Grignon (eds.), Out of the Count: the 1997 General Elections and Prospects of Democracy in Kenya, Kampala, Fountain Publishers, 2001, p. 50-71; H. Maupeu, 'Religion and the elections.' In H. Maupeu, M. Katumanga, W. Mitullah (eds.), The Moi Succession... .op. cit., p. 33-68.

47. Maisha Bora, meaning a good life, was the slogan taken up by ODM.

48. In the large towns of the country, violence was also manifest through looting of shops and supermarkets. 